Ken Higashimoto $\cdot$ Hidenobu Soejima • Takesi Katsuki

Tsunehiro Mukai

\title{
Identification of a novel single nucleotide polymorphism (SNP) in the human organic cation transporter-like 2-antisense (ORCTL2S) gene
}

\begin{abstract}
We found a single nucleotide polymorphism (SNP) in exon 3 of the human organic cation transporterlike 2-antisense (ORCTL2S) gene: a base substitution A266G which was confirmed by direct sequencing. Heterozygosity of the polymorphic alleles was 0.45 in a Japanese population. This polymorphism will be useful in the allelic expression analysis of the ORCTL2S gene.
\end{abstract}

Key words Imprinting $\cdot 11 \mathrm{p} 15.5 \cdot$ Single nucleotide polymorphism (SNP) · PCR-SSCP · ORCTL2S

\section{Introduction}

Imprinted genes are frequently found to cluster on particular chromosomes (Zemel et al. 1992). In the human, there are at least two common imprinted domains. One is the human chromosomal band 11p15.5, where the imprinted genes, H19, IGF2, KVLQT1, p57 ${ }^{K I P 2}$, and others are located (Zhang and Tycko 1992; Jinno et al. 1995; Giannoukakis et al. 1993; Lee et al. 1997; Matsuoka et al. 1996). The human $O R C T L 2 S$ is localized near the three imprinted genes, IPL, ORCTL2, and $p 57^{K I P 2}$ (Qian et al. 1997; Cooper et al. 1998). Thus, one would expect ORCTL2S to show imprinted status. In order to analyze its allelic expression, we searched and found a single nucleotide polymorphism (SNP) in exon 3 of $O R C T L 2 S$.

Polymerase chain reaction (PCR) primers

The PCR primers used were:

OR3F3: 5'-CAGGCTGACTGGAGGAAGGA-3' and OR3R: 5'-GCCGTTATCTATGCTATTCTCT-3'

K. Higashimoto $\cdot$ H. Soejima $\cdot$ T. Mukai $(\square)$

Department of Biochemistry, Saga Medical School, 5-1-1 Nabeshima, Saga 849-8501, Japan

Tel. +81-952-34-2260; Fax +81-952-34-2067

e-mail: mukait@post.saga-med.ac.jp

K. Higashimoto · T. Katsuki

Department of Oral Surgery, Saga Medical School, Saga, Japan
Primer labeling and PCR conditions

Before the PCR reaction, the primers were labeled by $[\gamma$ $\left.{ }^{32} \mathrm{P}\right] \mathrm{dATP}$, using a Kination kit (Toyobo, Tokyo, Japan), following the manufacturer's protocol. PCR was carried out in a total volume of $10 \mu \mathrm{l}$, containing $100 \mathrm{ng}$ genomic DNA, $0.1 \mu \mathrm{M}$ of each primer, $0.25 \mathrm{mM}$ of each dNTP, $1 \times$ Expand PCR buffer with $\mathrm{MgCl}_{2}$, and $0.35 \mathrm{U}$ Expand Taq polymerase (Boehringer-Mannheim, Mannheim, Germany), and performed as follows: an initial denaturation at $95^{\circ} \mathrm{C}$ for $5 \mathrm{~min}$, followed by 35 cycles of denaturation at $95^{\circ} \mathrm{C}$ for $20 \mathrm{~s}$, annealing at $53^{\circ} \mathrm{C}$ for $20 \mathrm{~s}$, and extension at $72^{\circ} \mathrm{C}$ for $30 \mathrm{~s}$, with a final extension at $72^{\circ} \mathrm{C}$ for $5 \mathrm{~min}$.

Single-strand conformation polymorphism (SSCP)

After the PCR reaction, $5 \mu$ each of the radiolabeled PCR product was added to $45 \mu \mathrm{l}$ of stop solution, which consisted of $95 \%$ formamide, $10 \mathrm{mM} \mathrm{NaOH}, 0.25 \%$ bromophenol blue, and $0.25 \%$ xylene cyanol. These mixtures were incubated at $94^{\circ} \mathrm{C}$ for $3 \mathrm{~min}$, then $1.5-\mu \mathrm{l}$ aliquots of each were loaded and electorophoresed on $0.5 \times$ Super Detection Solution (Toyobo) containing 5\% glycerol and $0.6 \times \mathrm{TBE}$ $(53.4 \mathrm{mM}$ Tris, $53.4 \mathrm{mM}$ boric acid, $1.32 \mathrm{mM}$ ethylene diamine tetraacetic acid [EDTA], at $4^{\circ} \mathrm{C}(7-8 \mathrm{~W}, 10 \mathrm{~h})$. After electrophoresis, the gel was dried, then exposed to the imaging plate for $30 \mathrm{~min}$, and analyzed with a BAS-2000 bio imaging analyzer (Fuji Film, Tokyo, Japan).

\section{Polymorphism and allele frequency}

The lower band of SSCP was generated from the A allele and the upper one from the $\mathrm{G}$ allele (Fig. 1). The estimated allele frequency of the A allele and the $\mathrm{G}$ allele in 50 normal volunteer Japanese is shown in Table 1.

Chromosomal localization. The human ORCTL2S gene was assigned to human chromosome 11p15.5 (Cooper et al. 1998). 


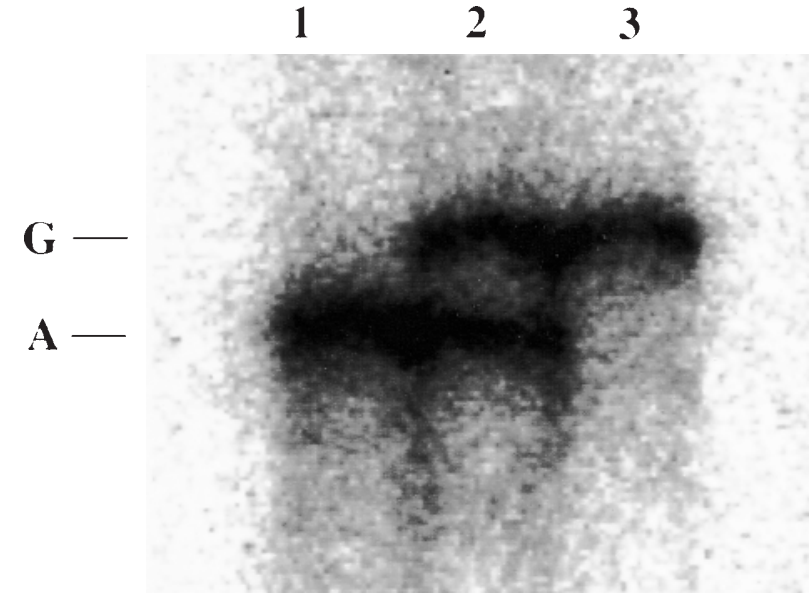

Fig. 1. Single nucleotide polymorphism of ORCTL2S. Lanes 1-3 indicate a homozygote for the A allele $(A)$, heterozygote $(\mathrm{A} / \mathrm{G})$, and a homozygote for the $\mathrm{G}$ allele $(G)$, respectively

Table 1. Allelic frequencies of single-strand conformation polymorphism in 50 normal Japanese individuals

\begin{tabular}{lll}
\hline Allele & Frequency & Heterozygosity \\
\hline A & 0.34 & 0.45 \\
G & 0.66 & \\
\hline
\end{tabular}

Acknowledgments This work was supported, in part, by a Health Science Research Grants (Research on Human Genome and Gene Therapy) from the Ministry of Health and Welfare of Japan.

\section{References}

Cooper PR, Smilinich NJ, Day CD, Nowak NJ, Reid LH, Pearsall RS, Reece M, Prawitt D, Landers J, Housman DE, Winterpacht A, Zabel BU, Pelletier J, Weissman BE, Shows TB, Higgins MJ (1998) Divergently transcribed overlapping genes expressed in liver and kidney and located in the 11p15.5 imprinted domain. Genomics 49:38-51

Giannoukakis N, Deal C, Paquette J, Goodyer CG, Polychronakos C (1993) Parental genomic imprinting of the human IGF2 gene. Nature Genet 4:98-101

Jinno Y, Ikeda Y, Yun K, Maw M, Masuzaki H, Fukuda H, Inuzuka K, Fujishita A, Ohtani Y, Okimoto T, Ishimaru T, Niikawa N (1995) Establishment of functional imprinting of the H19 gene in human developing placentae. Nature Genet 10:318-324

Lee MP, Hu RJ, Johnson LA, Feinberg AP (1997) Human KVLQT1 gene shows tissue-specific imprinting and encompasses BeckwithWiedemann syndrome chromosomal rearrangements. Nature Genet 15:181-185

Matsuoka S, Thompson JS, Edwards MC, Barletta JM, Grundy P, Kalikin LM, Harper JW, Elledge SJ, Feinberg AP (1996) Imprinting of the gene encoding a human cyclin-dependent kinase inhibitor, $p 57^{K I P 2}$, on chromosome 11p15. Proc Natl Acad Sci USA 93:30263030

Qian N, Frank D, O'Keefe D, Dao D, Zhao L, Yuan L, Wang Q, Keating M, Walsh C, Tycko B (1997) The IPL gene on chromosome $11 \mathrm{p} 15.5$ is imprinted in humans and mice and is similar to TDAG51, implicated in Fas expression and apoptosis. Hum Mol Genet 6:20212029

Zemel S, Bartolomei MS, Tilghman SM (1992) Physical linkage of two mammalian imprinted genes, $H 19$ and insulin-like growth factor 2 . Nature Genet 2:61-65

Zhang Y, Tycko B (1992) Monoallelic expression of the human H19 gene. Nature Genet 1:40-44 